\section{Pesticides use and its effect on soil bacteria and fungal populations, microbial biomass carbon and enzymatic activity}

\author{
Sanjay Arora ${ }^{1, *}$, Sumitra Arora ${ }^{2}$, Divya Sahni ${ }^{1}$, \\ M. Sehgal ${ }^{2}$, D. S. Srivastava ${ }^{3}$ and A. Singh $^{3}$ \\ ${ }^{1}$ ICAR-Central Soil Salinity Research Institute, \\ Regional Research Station, Lucknow 226 002, India \\ ${ }^{2}$ ICAR-National Centre for integrated Pest Management, \\ New Delhi 110 012, India \\ ${ }^{3}$ Krishi Vigyan Kendra, Sitapur II, Katia, Sitapur 261 145, India
}

The indiscriminate use of chemical pesticides disturbs the soil environment, thereby affecting flora and fauna including soil microflora, and also the physicochemical properties of the soil, viz. pH, salinity, alkalinity, leading to poor soil fertility. With the application of pesticides, possibilities exist that these chemicals may exert certain effects on non-target soil microorganisms. The soil microbial biomass plays an important role in the soil ecosystem, where they fulfill a crucial role in nutrient cycling and decomposition. A series of field experiments were conducted at farmer's field at Sitapur, UP with different modules of integrated pest management (IPM) including use of safe formulations. The impact of application of these pesticides on the soil properties including soil microbial populations, microbial biomass carbon and enzymatic activity was assessed. It was observed that soil microbial biomass $C$ content and dehydrogenase activity was influenced by IPM interventions.

Keywords: Dehydrogenase, fungal population, microbial biomass $\mathrm{C}$, pesticides, soil bacteria.

APPROXIMATELY 80,000 tonnes of pesticides are used annually in Indian agriculture ${ }^{1}$, mostly in the production of cotton $(45 \% \text { of total pesticide use })^{2}$, rice $(23 \%$ of total pesticide use), fruits and vegetables (about $8 \%$ of total pesticide use), and cereals, pulses, oilseeds and millets (about $6-7 \%$ of total pesticide use). The Indian states such as Haryana, Punjab and Uttar Pradesh have the largest pesticide consumption, using 45,000 tonnes of (technical grade) pesticides in 2000-01. This enhanced consumption has led to the depletion of soil fertility and a reduction in sustainable crop production ${ }^{3}$. With the increase in awareness of the adverse impacts of extensive pesticide use on the environment as well as ecology, and Integrated Pest Management (IPM) practices, the consumption of chemical pesticides has decreased by $27.69 \%$, from 66,360 tonnes during 1994-95 to 43,590 tonnes during 2001-02 (ref. 4).

*For correspondence. (e-mail: aroraicar@gmail.com)
Pesticides reaching the soil might disturb native metabolism or enzymatic activities ${ }^{5}$. Dehydrogenases occur intracellularly in all the living microbial cells and these enzymes are linked with microbial respiratory processes. Dehydrogenase activity in the soil system is an indicator of overall microbial activity of the soils ${ }^{6}$.

The soil microbial biomass is the labile pool of organic matter and acts as both source and sink of plant nutrients. It plays a crucial role in nutrient cycling and is important in maintaining soil fertility and nutrient concentration like microbial $\mathrm{C}, \mathrm{N}$ and $\mathrm{P}$ which are nutrients that are liberated after the death of micro-organisms. Changes in the microbial population in response to variation in soil conditions have serious implications for nutrient cycling with micro-organisms. Estimations of biologically active fractions of soil organic matter, like microbial biomass carbon might replicate changes in soil quality and therefore the productivity, that can in turn alter nutrient dynamics under different land uses ${ }^{7}$. Enzyme activity like phosphatase, dehydrogenase enzyme activity in the soil environment is considered to be a major contributor to overall soil microbial activity ${ }^{8}$ and, more recently, to soil quality ${ }^{9,10}$.

Soil microbial biomass is the early indicator of changing soil process and acts as a sturdy predictor of the chemical pesticide degradation capability of soil ${ }^{11}$. The microbial biomass consists primarily of bacteria and fungi that decompose crop residues and organic matter in the soil. This process releases nutrients, like nitrogen $(\mathrm{N})$, into the soil for plant uptake. About half the microbial biomass is found $10 \mathrm{~cm}$ within the surface of a soil profile and most of the nutrient release also occurs here. Generally, up to $5 \%$ of the total organic carbon and $\mathrm{N}$ in soil is contained in the microbial biomass at any one time. The value of the microbial biomass content of soil, the activity of the biomass and selected microbial nutrient process act as indicators of soil health. Soil microorganisms play a vital role in maintaining soil health, ecosystem functions and crop productivity. A complex matrix of organic and inorganic constituents of soil, particularly rhizosphere, creates a unique and dynamic environment for the microorganisms which affects plants and other associative microorganisms. Certain group of pesticides and the overdose of some pesticides have deleterious effect on soil biota.

In paddy, farmers in the area use different combinations of pesticides, that too in more than the recommended doses. Continuous use of pesticides could accumulate considerable amounts of pesticides and their degradation products in the soil ecosystem ${ }^{12}$. Pesticides that disrupt the activities of soil microorganisms could affect the nutritional quality of soils, leading to serious ecological consequences $^{13}$. Therefore, the present study was conducted in the paddy growing belt of Sitapur district (Uttar Pradesh) to ascertain the effect of pesticide use in paddy on soil microflora, soil microbial biomass $\mathrm{C}$ and enzymatic activities. 


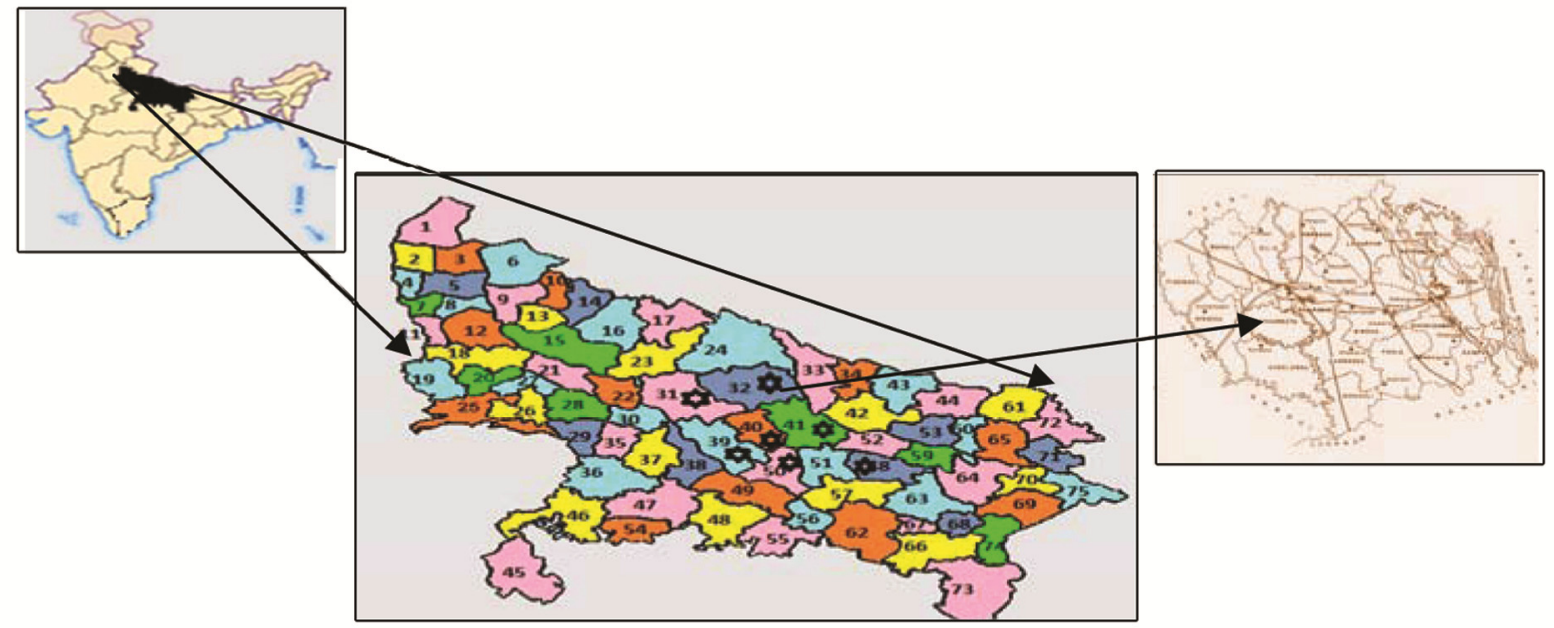

Figure 1. Study area.

Soil samples were collected from the rhizosphere of paddy from 20 locations in Sitapur district (UP) where the farmers use different types of pesticides in crops (Figure 1). Part of soil samples were kept fresh in a refrigerator for microbial and biochemical analysis and the other part was dried under shade and then ground in a mortar pestle and sieved through $2 \mathrm{~mm}$ sieve for physicochemical and nutrient analysis. Soil samples were analysed for $\mathrm{pH}, \mathrm{EC}, \mathrm{OC}$, av. N, total $\mathrm{N}$, carbonate, bicarbonate, chloride, exchangeable ions like $\mathrm{Ca}, \mathrm{Mg}, \mathrm{Na}$ and $\mathrm{K}$ as per standard methods. Soil microbial biomass $\mathrm{C}$ was estimated using fumigation-extraction method and dehydrogenase enzyme activity was assayed using $3 \%$ of 2,3,5-triphenyl tetrazolium chloride (TTC) solution as per standard procedure ${ }^{14,15}$.

Fresh soil samples were serially diluted in sterile normal saline and $0.1 \mathrm{ml}$ of aliquot from $10^{-2}$ to $10^{-4}$ dilutions and were spread onto nutrient agar medium using sterilized glass L-rod. Plating was done in duplicates and all the plates were incubated at $28^{\circ} \mathrm{C}$ for 5 days. After incubation, morphologically different bacterial colonies were selected and streaked on nutrient agar plants and incubated at $28^{\circ} \mathrm{C}$ for $48 \mathrm{~h}$. The number of viable bacterial cells per unit volume of the sample using agar plate media was enumerated. The inoculum sample was spread across the plate and the colonies that were formed after incubation were counted. The colonies are referred to as colony forming units (CFU). After the CFUs were counted on the plate, they were divided by the volume plated to determine the concentration of cells in the sample. Based on the difference in cultural morphology such as colour, texture, consistency and size, limited number of representative isolates were selected from the entire sample for further study. The selected isolates were subcultured in nutrient agar slants and were preserved at $4^{\circ} \mathrm{C}$ in a refrigerator. Phenotypic characters, like Grams' reac- tion, motility, catalase, oxidase activity and other biochemical tests of the selected isolates were performed following standard procedures. Identification of isolated bacterial strain was done by $16 \mathrm{~S}$ ribosomal RNA gene sequencing. Genomic DNA of bacterial isolate was amplified with universal primer 27F1 (5-AGAGTTTGAT CMTGGCTCAG-3) and 1494Rc (5-TACGGCTACCTT GTTACGAC-3).

The purified amplified PCR product of $1.5 \mathrm{~kb}$ was sent to Xcelris Genomics Labs Ltd for sequencing. For screening of soil bacteria for salt $(\mathrm{NaCl})$ tolerance, isolates were inoculated onto nutrient agar medium supplemented with different salt concentrations $(2.5 \%, 5 \%, 10 \%$ and $15 \%$ of $\mathrm{NaCl})$. All the plates were incubated at $28^{\circ} \mathrm{C}$ for 5 days in BOD incubator and bacterial growth was observed every $24 \mathrm{~h}$. Correlation was worked out among different soil properties and soil-biochemical parameters.

An incubation experiment was conducted in the laboratory for 90 days to monitor the effect of different pesticides on soil microbial activity and mineralization of carbon in paddy soils. For this $\mathrm{C}$ mineralization in soil as influenced by $1 \mathrm{ppm}$, four commonly used pesticides, viz. chlorpyriphos, 2,4-D, carbendazim and carbofuron were applied in the paddy soil of Sitapur and equilibrated. The experiment was laid in completely randomized block design with three replications. The $\mathrm{C}$ mineralization in terms of carbon dioxide evolution from the soil was studied by following the method proposed by Pramer and $\mathrm{Schmidt}^{16}$. The treated soils in flasks were incubated at $60 \%$ water holding capacity (WHC) and $28 \pm 1^{\circ} \mathrm{C}$ temperature. The flasks contained $0.1 \mathrm{~N} \mathrm{NaOH}$ in a vial, to trap evolved $\mathrm{CO}_{2}$. The vials were removed at $0,1,3,5$, 7, 15, 30, 45, 60 and 90 days of incubation for estimation of mineralized C. Three sets of soil samples, $10 \mathrm{~g}$ each, were taken from the flask for estimation of microbial biomass carbon (MBC). One set of soil was fumigated 


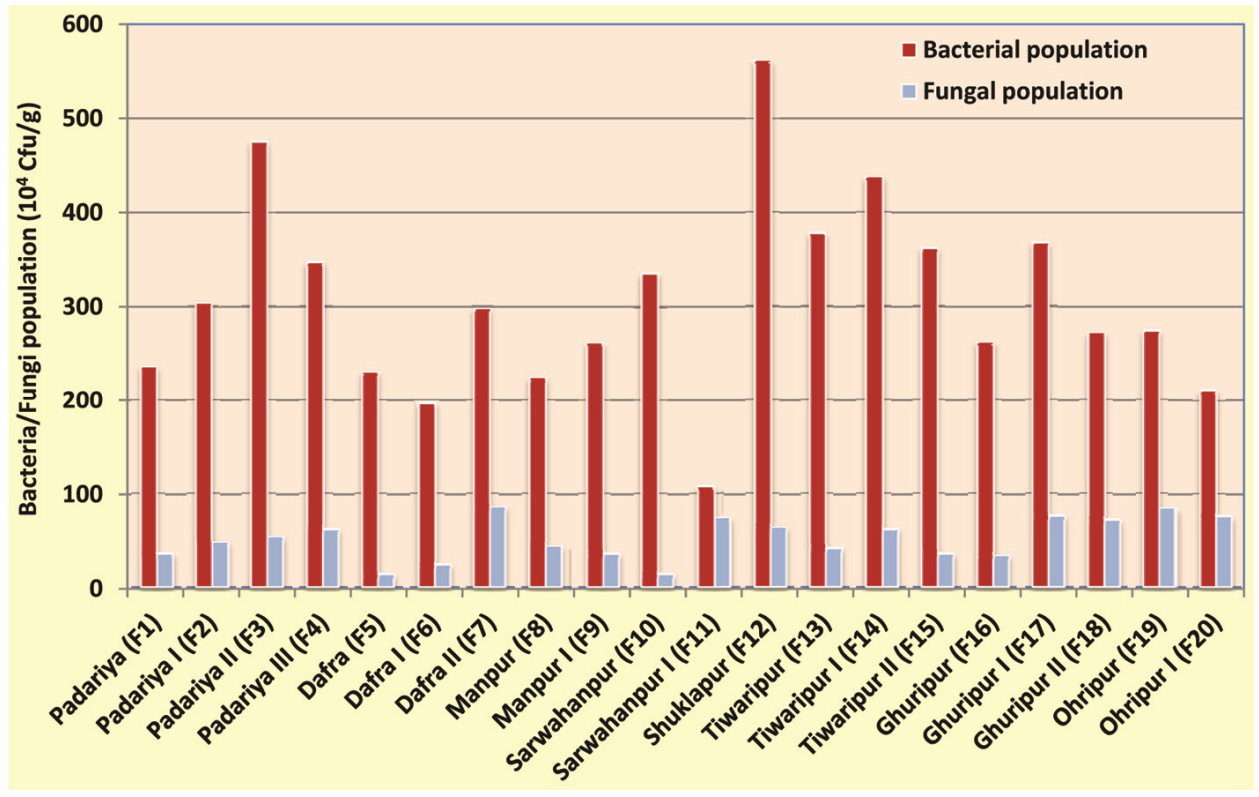

Figure 2. Soil bacteria and fungi population.

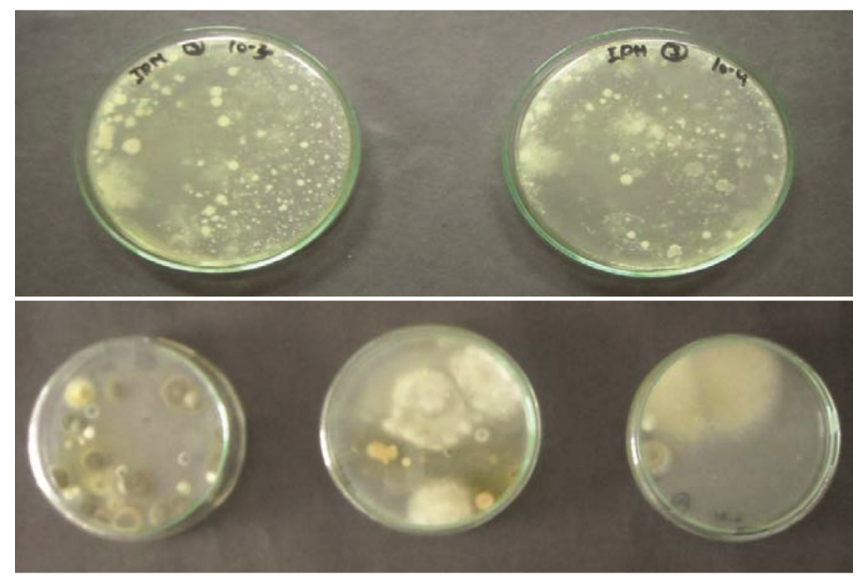

Figure 3. Bacterial and fungal isolation from paddy soil.

Table 1. Properties of soil

\begin{tabular}{lcc}
\hline Soil properties & Range & Mean \\
\hline Soil $\mathrm{pH}(1: 2)$ & $6.35-8.64$ & 7.82 \\
$\left.\mathrm{EC}(\mathrm{dS} \mathrm{m})^{-1}\right)$ & $0.04-1.11$ & 0.46 \\
Organic $\mathrm{C}\left(\mathrm{g} \mathrm{kg}^{-1}\right)$ & $2.1-5.4$ & 3.42 \\
Available $\mathrm{N}\left(\mathrm{kg} \mathrm{ha}^{-1}\right)$ & $81.9-179.8$ & 128.6 \\
Available $\mathrm{P}\left(\mathrm{kg} \mathrm{ha}^{-1}\right)$ & $5.9-19.9$ & 12.5 \\
Available $\mathrm{K}\left(\mathrm{kg} \mathrm{ha}^{-1}\right)$ & $154.3-232.2$ & 180.7 \\
Textural class & Loamy sand to silty clay loam & - \\
\hline
\end{tabular}

using ethanol-free chloroform placed in a vacuum desiccators ${ }^{17}$. The $\mathrm{CO}_{2}-\mathrm{C}$ that evolved from the soil was measured by back titrating the unspent alkali in the vial with standard $\mathrm{H}_{2} \mathrm{SO}_{4}$ for estimating potential carbon mineralization ${ }^{18}$. Periodic observations were recorded for mineralized $\mathrm{C}$ and $\mathrm{MBC}$ on $0,1,3,5,7,15,30,45,60$ and 90 days of incubation.

The surface soils of the 20 paddy fields of Sitapur were analysed for various physico-chemical properties. The soil $\mathrm{pH}$ ranged from 6.35 to 8.64 and electrical conductivity (EC) ranged from 0.04 to $1.11 \mathrm{dS} \mathrm{m}^{-1}$. Soil organic carbon content varied from 2.1 to $5.4 \mathrm{~g} \mathrm{~kg}^{-1}$ and the soils were loamy sand to silty clay loam in texture (Table 1). Available N, P and K content ranged from 81.9 to 179.8 , 5.9 to 19.9 and 154.3 to $232.2 \mathrm{~kg} \mathrm{ha}^{-1}$ respectively.

The population $\left(\mathrm{cfu} \mathrm{g}^{-1}\right)$ of bacteria ranged from $196 \times 10^{4}$ to $56 \times 10^{5}$. Bacterial population in paddy soil of Shuklapur was maximum followed by Padariya II and Tiwaripur I. Least bacterial load was observed in paddy rhizosphere soil of Sarwahanpur I from Sitapur (Figure 2). A total of 137 bacterial isolates were isolated from soils. Most of the isolated bacteria were Gram-positive and were rod shaped. There was great variation in their colony characteristics (Figure 3). Gram's staining showed 103 were cocci while 34 were bacilli. Similarly, fungi isolated on potato dextrose agar was found to be maximum in soil of Dafra II followed by Ohripur and Ghuripur. In paddy soil of Dafra and Sarwahanpur, fungal population was minimum. The dominant fungal isolates were Aspergillus, Cladosporium, Rhizopus, Trichoderma and Penicillium.

Soil bacterial populations drastically reduced from $6.2 \times 10^{5} \mathrm{cfu} \mathrm{g}^{-1}$ to $1.8 \times 10^{4} \mathrm{cfu} \mathrm{g}^{-1}$ on nutrient agar after $24 \mathrm{~h}$ of growth in soil from farmers' practice of using pesticides. Similarly, where safer pesticides were used, bacterial load in soil enhanced from $5.4 \times 10^{4} \mathrm{cfu} \mathrm{g}^{-1}$ to $4.1 \times 10^{5} \mathrm{cfu} \mathrm{g}^{-1}$. Soil microbial activity has been reported as a criteria for evaluating pesticide toxicity ${ }^{19}$. Pandey and Singh $^{20}$ reported that application of chlorpyriphos 


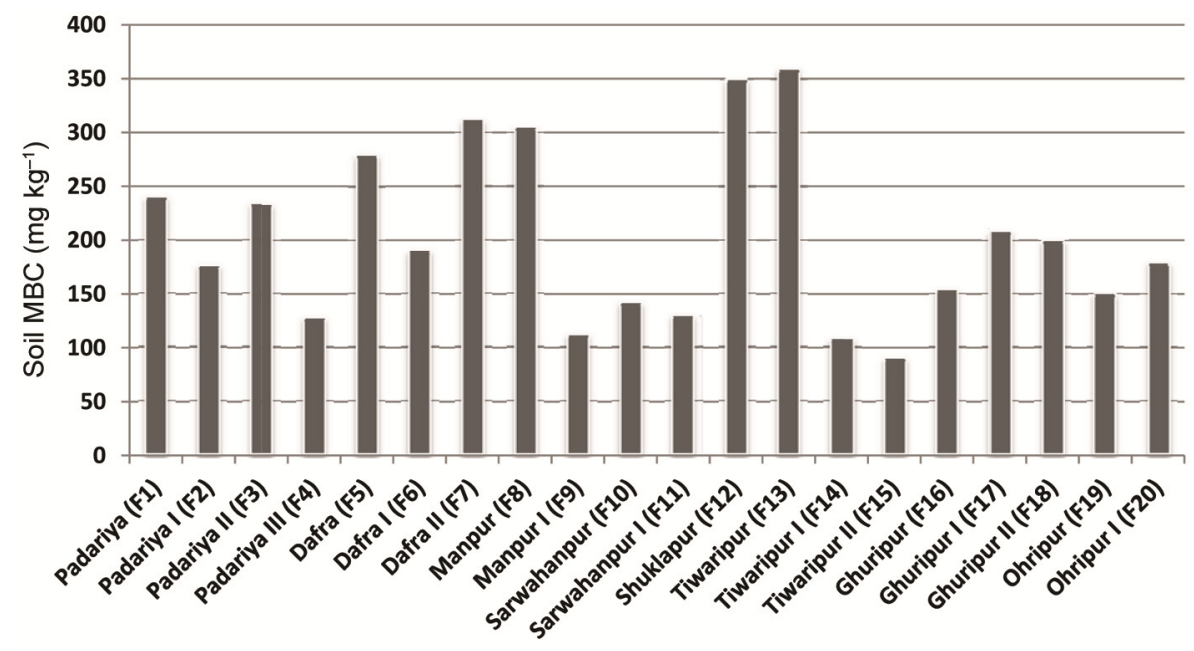

Figure 4. Soil MBC content in rhizosphere of paddy.

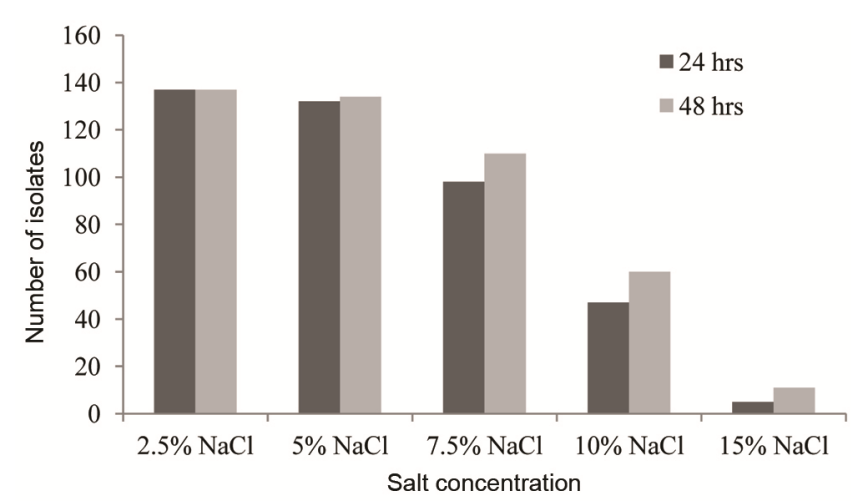

Figure 5. Screening of bacterial isolates for salt tolerance in media.

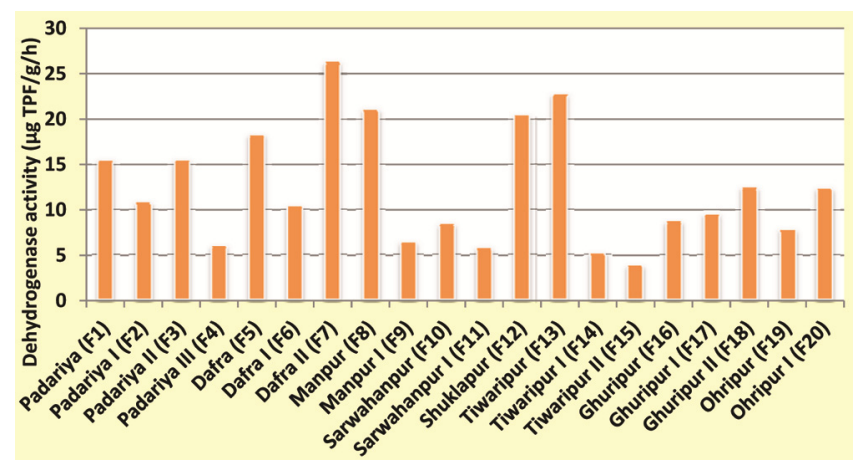

Figure 6. Soil dehydrogenase activity.

Table 2. Screening of bacterial isolates for tolerance to $\mathrm{pH}$ of media

\begin{tabular}{rcc}
\hline $\mathrm{pH}$ & $24 \mathrm{~h}$ & $48 \mathrm{~h}$ \\
\hline 5 & 125 & 126 \\
7 & 134 & 134 \\
9 & 132 & 132 \\
11 & 134 & 129 \\
\hline
\end{tabular}

reduced bacterial population while there was significant increase in fungal population.

Microorganisms form an important part of the soil food web; thus microbial biomass is considered to be a measure of potential microbiological and ecosystem function$\mathrm{ing}^{21}$. Soil microbial biomass $\mathrm{C}$ (SMBC) was a maximum of $360 \mathrm{mg} \mathrm{kg}^{-1}$ in $\mathrm{F} 13$ from farmers' paddy field of Tiwaripur followed by $350 \mathrm{mg} \mathrm{kg}^{-1}$ in F12 field at Shuklapur, Manpur and Sitapur. Minimum amount of SMBC was noticed to be $90 \mathrm{mg} \mathrm{kg}^{-1}$ in F15 field from Tiwaripur II (Figure 4).

In field conditions, soil MBC content after harvest of paddy showed variations from $60 \mathrm{mg} \mathrm{kg}^{-1}$ to $182 \mathrm{mg} \mathrm{kg}^{-1}$ where safer pesticides were used, whereas in modules where farmers used overdoses of pesticides, SMBC content ranged between 24 and $118 \mathrm{mg} \mathrm{kg}^{-1}$. Mehta and Arora $^{22}$ also reported variability in SMBC content under different land uses in coastal saline soils. Positive effect of organic manures on soil microbial biomass content under paddy was also reported ${ }^{23}$.

Out of the total bacterial isolates, 132 isolates tolerated $5 \% \mathrm{NaCl}$ concentration while 47 isolates were able to tolerate $10 \%$ and only 5 could tolerate $15 \% \mathrm{NaCl}$ concentration in the media (Figure 5). All the bacterial isolates were tolerant to alkaline $\mathrm{pH}$ up to 11 in the media maintained by $1 \mathrm{~N} \mathrm{NaOH}$ (Table 2). It was observed that at $48 \mathrm{~h}$ there was some effect and only 132 and 129 isolates out of 134 survived upto $\mathrm{pH} 9$ and 11 respectively.

Almost all the isolates could tolerate $\mathrm{pH}$ up to 9 while only 121 out of 132 could tolerate $\mathrm{pH}$ up to 11 in the media (Table 3). Most of the isolated bacteria were Grampositive and rod shaped. There was a wide variation in their colony characteristics. Gram's staining showed that 103 were cocci, while 34 were bacilli. Eleven isolates were yellow pigmented and 46 were creamy or off white. The dominant bacterial isolates were gene sequenced for molecular identification and the results are presented in 
RESEARCH COMMUNICATIONS

Table 3. Biochemical characterization of selected bacterial isolates

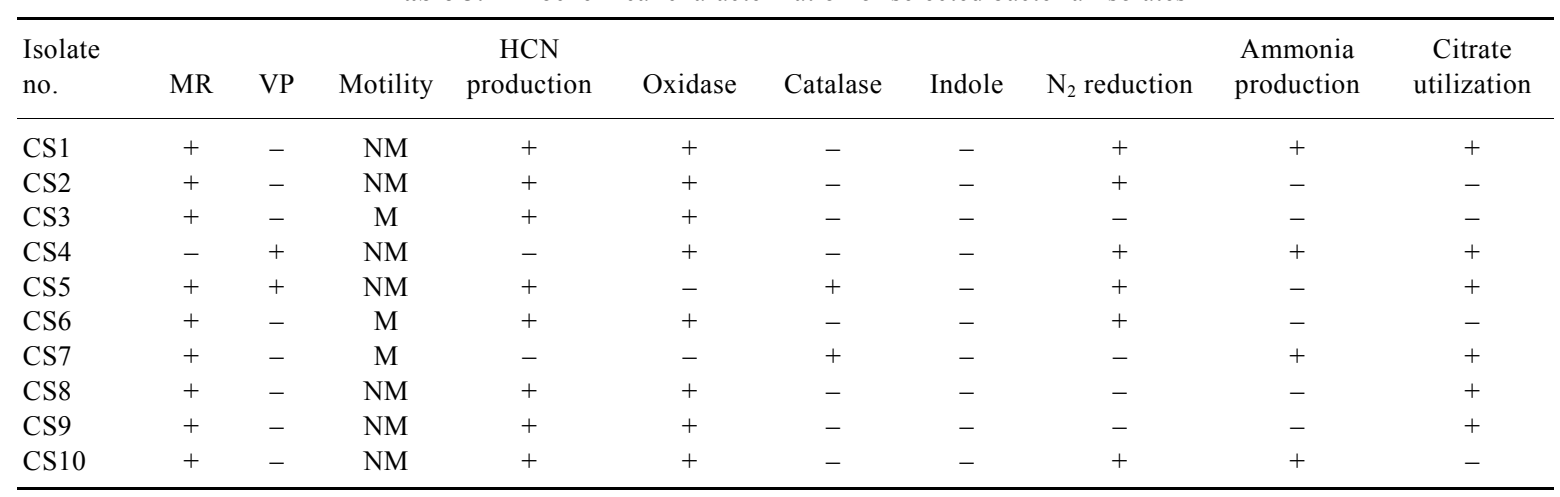

NM, Non-motile; M, motile.

Table 4. Genetic identification of dominant isolated soil bacteria

\begin{tabular}{ll}
\hline Isolate no. & Molecular identification \\
\hline CS1 & Enterobacter sp. \\
CS2 & Bacillus sp. \\
CS3 & Bacillus pumilus \\
CS4 & Aneurinibacillus migulanus \\
CS5 & Bacillus subtilis \\
CS6 & Bacillus megaterium \\
CS7 & Bacillus flexus \\
CS8 & Pseudomonas indica \\
CS9 & Achromobacter denitrificans \\
CS10 & Paenibacillus sp. \\
\hline
\end{tabular}

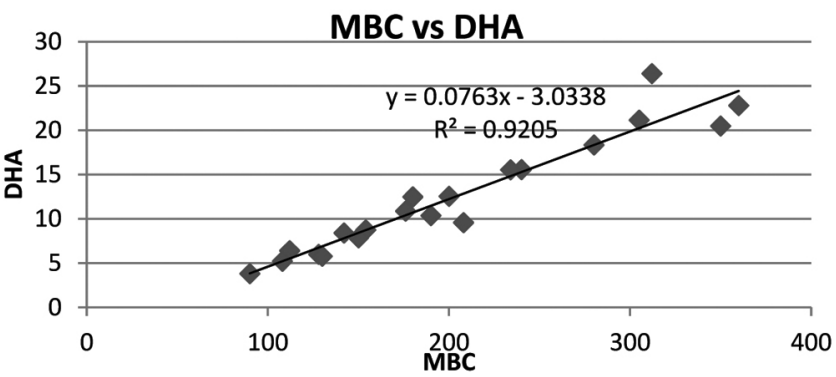

Figure 7. Relationship between soil MBC and dehydrogenase activity.

Table 4. The dominant fungal isolates were identified based on classical taxonomy through microscopic examination and were found to belong to fungal groups Aspergillus, Cladosporium, Rhizopus, Trichoderma and Penicillium.

The selected isolates were biochemically characterized as per the standard procedures and it was observed that out of the selected 10 salt tolerant bacterial isolates, 6 were able to reduce nitrate and only four produced ammonia. Six isolates were positive for citrate utilization and only two were negative for HCN production. None of the isolate produced indole. Oxidase and catalase enzyme activity was found to be positive in 8 and 2 bacterial isolates respectively. Only three bacterial isolates were observed to be motile (Table 3 ).

Dehrydrogenase activity was a maximum of $26.4 \mu \mathrm{g}$ $\mathrm{TPF} / \mathrm{g} / \mathrm{h}$ in soil from the paddy field of Dafra (F7) followed by $22.8 \mu \mathrm{g} \mathrm{TPF} / \mathrm{g} / \mathrm{h}$ in soil of F13 (Tiwaripur) (Figure 6). Minimum activity of dehydrogenase enzyme (3.82 $\mu \mathrm{g} \mathrm{TPF} / \mathrm{g} / \mathrm{h}$ ) was observed in paddy soil from Tiwaripur II (F15). Variability in soil dehydrogenase activity under different land uses in saline soils has been reported earlier ${ }^{22}$.

Pronounced positive relationship exists between colony forming units of microbes (bacterial counts) from soils and dehydrogenase activity of soils. The MBC was positively correlated with DHA ( $r=0.920$; Figure 7$)$. Positive relationship between these soil bio-chemical properties has also been reported in coastal saline soils of Sundarbans $^{24}$.

In the laboratory incubation experiment, it was observed that soils applied with 2,4-D showed drastic reduction in dehydrogenase activity compared to control. It was observed that there was reduction of dehydrogenase activity in soil by $42.97 \%, 58.24 \%, 28.68 \%$ and $43.96 \%$ when applied with chlorpyriphos, 2,4-D, carbofuron and carbendazim respectively, compared to control soil (Figure 8). The negative impact of chemical pesticides on soil enzymes like hydrolases and dehydrogenase activities has been widely reported by several studies ${ }^{25-27}$.

To assess the effect of pesticides on soil $\mathrm{C}$ mineralization, a laboratory incubation study was conducted with paddy soil of Sitapur. It was observed that soils applied with 2,4-D showed reduction in soil organic $\mathrm{C}$ content as well as total C content compared to control (Figure 9). There was reduction in soil organic $\mathrm{C}$ content from $4.4 \mathrm{~g} \mathrm{~kg}^{-1}$ in control to $4.2 \mathrm{~g} \mathrm{~kg}^{-1}$ in soils applied with chlorpyriphos or carbofuron, while the reduction was $4 \mathrm{~g} \mathrm{~kg}^{-1}$ in soil having residue of 2,4-D and carbendazim. Total C content in soil was found to decrease by $17.3 \%$, $15.4 \%$ and $3.8 \%$ when soil was applied with $2,4-\mathrm{D}$, carbofuron and carbendazim respectively, compared to 


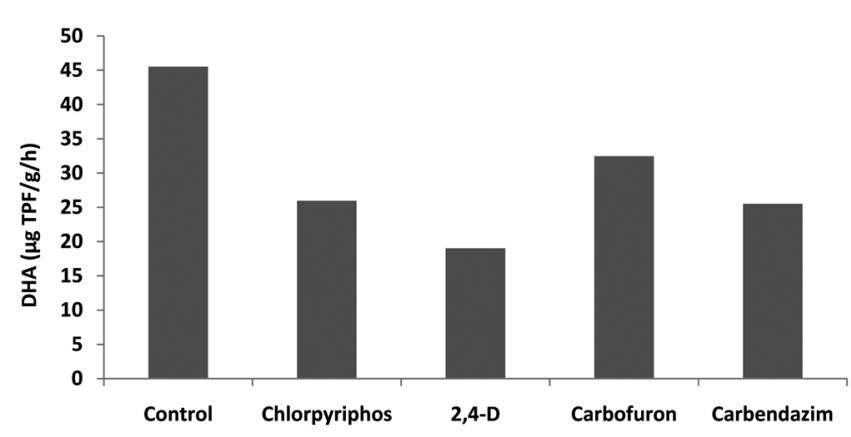

Figure 8. Effect of pesticide on soil dehydrogenase activity.

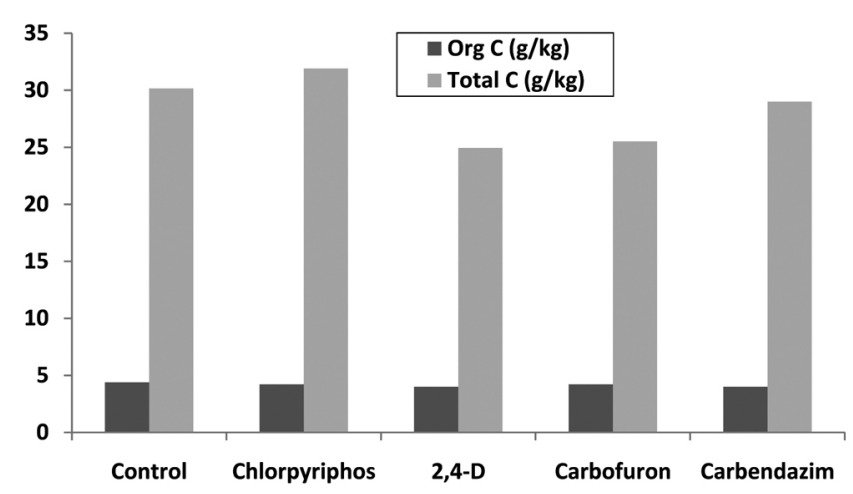

Figure 9. Effect of pesticide on soil organic and total $\mathrm{C}$ content.

control soil. Changes in soil $\mathrm{C}$ pool was observed earlier when organic manures were added to soil under cultivation with paddy ${ }^{28}$.

It was observed that 2,4-D application resulted in maximum decline of soil DHA compared to chlorpyriphos, carbofuron and carbendazim. There was not much variation on soil organic $\mathrm{C}$ when pesticides were applied. However, maximum decrease in soil total organic $\mathrm{C}$ occurred in soils having residues of 2,4-D (Figure 9).

The enhanced and indiscriminate use of chemical pesticides has led to the depletion of soil fertility, microbial populations and reduction in crop production. The impact of commonly used pesticides in paddy was assessed on the soil properties including soil microbial populations, MBC and enzymatic activity. Soil bacterial populations were drastically reduced in soil from farmers' practice of using pesticides. In the soils applied with 2,4-D, reduction in soil organic $\mathrm{C}$ content and total $\mathrm{C}$ content was observed. This also resulted in maximum decline of soil dehydrogenase activity (DHA) compared to chlorpyriphos, carbofuron and carbendazim. In the study it was found that carbofuron, chlorpyriphos and carbendazim application has less adverse effect on soil biological health compared to 2,4-D application.

1. Srinivasan, G., Panel for reduced use of chemical pesticides. Hindu Business Line, 5 November 1997.
2. Dhaliwal, G. S. and Pathak, M. D., Pesticides in the developing world: a boon in ban. In Pesticides: their Ecological Impact in Developing Countries (eds Dhaliwal, G. S. and Singh, B.), Commonwealth Publishers, New Delhi, 1993, pp. 1-29.

3. Sharma, M. C., Biopesticides: potential for Indian agriculture. In Biotechnological Strategies in Agro-Processing (eds Marwaha, S. S. and Arora, J. K.), Asia Tech, New Delhi, 2003, pp. 105112.

4. Kalia, A. and Gosal, S. K., Effect of pesticide application on soil microorganisms. Arch. Agro. Soil Sci., 2011, 57(6), 569-596.

5. Topp, E., Vallaeys, T. and Soulas, G., Pesticides: microbial degradation and effects on microorganisms. In Modern Soil Microbiology (eds van Elsas, J. D., Trevors, J. T. and Wellington, E. M. H.), Marcel Dekker, New York, 1997, pp. 547-575.

6. Bolton, H., Elliot, L. F., Papendick, R. I. and Bezdicek, D. F., Soil microbial biomass and selected soil enzymes activities: effect of fertilization and cropping practices. Soil Biol. Biochem., 1985, 17, 297-302.

7. Kara, O. and Bolat, I., The effect of different land uses on soil microbial biomass $\mathrm{C}$ and $\mathrm{N}$ in Bartin Province. Turk J. Agric., 2008, 32, 281-288.

8. Frankenberger, W. T. and Dick, W. A., Relationships between enzyme activities and microbial growth and activity indices in soil. Soil Sci. Soc. Am. J., 1983, 47, 945-951.

9. Visser, S. and Parkinson, D., Soil biological criteria as indicators of soil quality, soil microorganisms. Am. J. Alternative Agric., 1992, 7, 13-17.

10. Dick, R. P., Doran, J. V., Coleman, D. C., Bezdicek, D. F. and Stewart, B. A., Defining soil quality for a sustainable environment. Soil enzyme activities as indicators of soil quality. Soil Science Society of America, and American Society of Agriculture, Madison, WI, USA, 1994, pp. 107-124.

11. Voos, G. and Groffman, P. M., Relationship between microbial biomass and dissipation of 2,4-D and Dicamba in soil. Biol. Fertil. Soils, 1997, 24, 106-110.

12. Kumar, A. et al., Microbial biomass and carbon mineralization in agricultural soils as affected by pesticide addition. Bull. Environ. Contam. Toxicol., 2012, 88, 538-542.

13. Handa, S. K., Agnihotri, N. P. and Kulshreshtha, G., Pesticide Residues; Significance, Management and Analysis, Research Periodicals and Book Publishing House, Texas, 1999.

14. Voroney, R. P., Winter, J. P. and Begaert, R. P., Soil microbial biomass C and N. In Soil Sampling and Methods of Analysis (ed. Carter, M. R.), CRC Press, Boca Raton, Florida, 1993, pp. 277286.

15. Klein, B. A., Loh, T. C. and Goulding, R. L., A rapid procedure to evaluate the dehydrogenase activity of soils low in organic matter. Soil Biol. Biochem., 1971, 3, 385-387.

16. Pramer, D. E. and Schmidt, E. L., Experimental Soil Microbiology, Burges Publishing Co. Ltd, Minneapolis, 15. Minnesota, USA, 1964, pp. 31-32.

17. Joergensen, R. G., The fumigation-extraction method to estimate soil microbial biomass: calibration of the kEC value. Soil Biol. Biochem., 1996, 28, 25-31.

18. Zibilski, L. M., Carbon mineralization. In Methods of Soil Analysis, Part 2 Microbiological and Biochemical Properties (eds Bingham, J. M. and Mickelson, S. H.), SSSA, Book Series No. 5. ASA, SSSA, Madison, 1994.

19. Jones, W. J. and Ananyeva, N. D., Correlations between pesticide transformation rate and microbial respiration activity in soil of different ecosystems. Biol. Fertil. Soils, 2001, 33, 477-483.

20. Pandey, S. and Singh, D. K., Total bacterial and fungal population after chlorpyrifos and quinalphos treatments in groundnut (Arachis hypogaea L.) soils. Chemosphere, 2004, 55, 283-290.

21. Rath, A. K., Ramakrishnan, B., Kumaraswamy, S., Bharati, K., Singla, P. and Sethunathan, N., Effect of pesticides on microbial biomass of flooded soil. Chemosphere, 1998, 37, 661-671. 
22. Mehta, M. and Sanjay Arora, Soil microbial biomass and activity in salt affected coastal soils under different land uses. In: Proceedings of National Conference on 'Advanced Trends in Applied Sciences and Technology', SES, SICE, Surat, 2012, pp. 433-437.

23. Khursheed, S., Sanjay Arora and Ali, T., Effect of different organic sources on biochemical properties in Typical Inceptisols of Jammu. Prog. Agric., 2012, 12(2), 348-353.

24. Tripathi, S., Chakraborty, A., Chakrabarti, K. and Bandyopadhyay, B. K., Enzyme activities and microbial biomass in coastal soils of India. Soil Biol. Biochem., 2007, 39, 2840-2848.

25. Perucci, P. and Scarponi, L., Effects of the herbicide imazetapir on soil microbial biomass and various soil enzyme activities. Biol. Fertil. Soils, 1994, 17, 237-240.

26. Menon, P., Gopal, M. and Parsad, R., Effects of chlorpyrifos and quinalphos on dehydrogenase activities and reduction of $\mathrm{Fe}^{3}$ in the soils of two semi-arid fields of tropical India. Agric. Ecosyst. Environ., 2005, 108, 73-83.

27. Schuster, E. and Schroder, D., Side-effects of sequentially and simultaneously applied pesticides on non-target soil microorganisms: Laboratory experiments. Soil Biol. Biochem., 1990, 22, 375 383 .

28. Khursheed, S., Arora, S. and Ali, T., Effect of organic sources of nitrogen on rice (Oryza sativa) and soil carbon pools in Inceptisols of Jammu. Int. J. Environ. Pollut. Solu., 2013, 1, 17-21.

ACKNOWLEDGEMENTS. The work was conducted in an interinstitutional (CSSRI-NCIPM) collaborative project by a multidisciplinary team. We thank ICAR for extending funding support through NCIPM and Director, CSSRI, Karnal and Head, RRS, Lucknow for providing necessary facilities.

Received 2 September 2015; revised accepted 3 November 2018

doi: $10.18520 / \mathrm{cs} / \mathrm{v} 116 / \mathrm{i} 4 / 643-649$

\section{Enhancing the anti-tyrosinase activity of a hypersaline Kitasatospora sp. SBSK430 by optimizing the medium components}

\author{
Michelle S. Fernandes and Savita Kerkar* \\ Department of Biotechnology, Goa University, Goa 403 206, India
}

Tyrosinase inhibitors from natural resources have been gaining importance in pharmaceutical and horticultural applications. A full factorial central composite design was used to study the interactive effect of three variables, i.e. D-mannitol, yeast extract and sodium chloride of the fermentation medium for maximizing anti-tyrosinase activity $\mathbf{( 7 5 . 5 \% )}$ of a hypersaline actinobacteria, Kitasatospora sp. SBSK430. A quadratic model was found to fit the anti-tyrosinase activity

*For correspondence. (e-mail: drsavitakerkar@gmail.com)
$\left(R^{2}=0.948\right)$. Response surface analysis revealed that the optimum values of the medium components were $15 \mathrm{~g} / \mathrm{l}$ D-mannitol, $5.6 \mathrm{~g} / \mathrm{l}$ yeast extract and $1.2 \mathrm{~g} / \mathrm{l}$ sodium chloride. Tyrosinase inhibition activity was enhanced 1.1-fold, using this approach.

Keywords: Actinobacteria, anti-tyrosinase, fermentation medium, hypersaline, Kitasatospora sp.

ENZYMES are vital proteins involved in regulating various biochemical cycles in a biological system. They are also responsible for various reactions, and associated with several human disorders. Apart from enzymes, enzyme inhibitors have been extensively examined; not only to study the structure of the enzyme and its mechanism, but also for its application in other sectors such as agriculture $^{1,2}$, cosmetics ${ }^{2,3}$ and pharmaceuticals ${ }^{2,4}$. The enzyme tyrosinase (EC 1.14.18.1) has been gaining importance due to its widespread applications. It is a key enzyme responsible for the production of melanin, causing hyperpigmentation in the skin and undesirable browning of fruits and vegetables 5 . Thus, the search for a novel tyrosinase inhibitor is important.

Marine microorganisms are metabolically and physiologically different from terrestrial ones, owing to extreme environments such as high temperature and salinity, and low organic matter; thereby providing a potential source for novel and diverse compounds ${ }^{6}$. Among bacteria, actinobacteria are a renowned source of bioactive natural compounds with applications in medicine, agriculture and industry. They produce diverse secondary metabolites such as enzymes ${ }^{7,8}$, antibiotics ${ }^{9,10}$, probiotics $^{8}$, biosurfac$\operatorname{tants}^{7}$ and enzyme inhibitors ${ }^{11,12}$; Streptomyces being the major candidate ${ }^{13-15}$. Imada ${ }^{12}$ reported different types of enzyme inhibitors from marine actinobacteria, viz. glucosidase, $N$-acetyl-beta-D-glucosaminidase, pyroglutamyl peptidase and amylase inhibitors. Tyrosinase inhibitors have been reported from various natural and synthetic sources, highlighting their industrial relevance $e^{2,3,16-18}$. Researchers are turning towards metabolites from natural sources for various applications. Fernandes and Kerkar ${ }^{19}$ have reviewed tyrosinase inhibitors produced by microorganisms; with major inhibitors reported from fungi and Streptomyces species ${ }^{19}$.

The genus Kitasatospora, classified under Actinobacteria, has been reported as a producer of many bioactive compounds ${ }^{20-23}$. There are several reports of Kitasatospora producing novel bioactive compounds showing different activities $^{24}$. The genus is reported to exhibit various activities which include antimicrobial activity ${ }^{21,25,26}$, proteosome inhibitor ${ }^{23,27}$ and proteinase inhibitor ${ }^{28,29}$. Therefore, this genus could be the source of a new compound of biological importance.

Growth improvement of the organism is possible by manipulating its culturing conditions, in terms of nutritional and physical parameters. Various regulatory 